\title{
Article
}

\section{Comparative overview of different fish feed industries in Noakhali region of Bangladesh}

\author{
Sabiha Khatun $^{1 *}$, Md. Mofizur Rahman ${ }^{2}$ and Chayan Chandra Sarkar ${ }^{1}$ \\ ${ }^{1}$ Department of Fisheries Management, Faculty of Fisheries, Bangladesh Agricultural University, Mymensingh- \\ 2202, Bangladesh \\ ${ }^{2}$ Department of Fisheries and Marine Science, Faculty of Fisheries, Noakhali Science and Technology \\ University, Sonapur, Noakhali-3802, Bangladesh
}

${ }^{*}$ Corresponding author: Sabiha Khatun, Department of Fisheries Management, Faculty of Fisheries, Bangladesh Agricultural University, Mymensingh-2202, Bangladesh. Phone: +8801760236402; E-mail: sabihasathy22@gmail.com

Received: 07 December 2017/Accepted: 19 December 2017/ Published: 28 December 2017

\begin{abstract}
Aqua feeds have been considered as a major subsector in aquaculture. About 25 commercial fish feed industries in Bangladesh are now formulating over 1 million tones of commercial pelleted feed for the use by aquaculture farmers. A survey of different fish feed industries, their produced feed, used raw materials, machineries, distribution and marketing channel was carried out in 2015 at Noakhali of Bangladesh. Four fish feed industries were found having legal permission to produce fish feed in Noakhali. These were Globe-agro vet Ltd, Partex agro fish feed Ltd, Setu feed mills and R.P (Rasulpur) fish feed Ltd with an area of 9, 3, 2 and 3.5 acre, respectively. They used different types of machineries. Maximum machineries were found in Globe-agro vet Ltd. They used 19 types of raw materials where some were local and some were imported. Maximum raw materials were found in Globe-agro vet Ltd and they used 16 types of raw materials. Four types of fish feed were being produced in four fish feed industries and these are nursery, starter, grower, finisher. Square company was common of different raw materials supplier. Feed companies were linked with other business and take loan from local NGO and foreign organization. Their production capacity was not same rate all round the year. They like to produce feed from March to October. There was not so far difference in proximate composition of surveyed feed industries. Protein ranged at 28-35\%, Lipid 5-8 \%, moisture 10-12 \% and Ash 12-18 \%. The government should move forward with financial as well as technical support for the expansion and modernization of fish feed industries with a view to protecting the nature from incursive pollutants generated during feed manufacturing process.
\end{abstract}

Keywords: commercial feed; machineries; raw materials; finished product; proximate composition; marketing channel

\section{Introduction}

With the increasing demand for food fish and the decline in capture fisheries production, aquaculture in Bangladesh is heading towards intensification. This shift from low density to high density culture i.e. traditional to semi intensive or intensive culture is consequently leading to an unprecedented in the demand for feeds more than that of fertilizers. Farmers shift gradually from no feed, through the use of aquaculture systems depend upon be nutritionally adequate and commercial for the sound adequate supply of low cost feeds with high nutritional quality. The feed must be nutritionally adequate and commercial for the sound operation of a fish farm.

Over the last decade, dramatic increases in the production of a variety of species from commercial aquaculture systems and sharp increases in per capita fish consumption have occurred in Bangladesh. This transition has 
been made possible by widespread adoption of semi-intensive and intensive production practices, accompanied by growth in the production and use of aqua feeds (Rashid et al., 2013a). In the past 5 years, an estimated 1 million tones of commercially formulated pelleted feed have been produced, and between 0.3 and 0.4 million tones of feeds produced by micro- and small-enterprises at village level (Rashid et al., 2013b) Better feed composition will result in higher fish production and lower feed cost. The demand for quality products at low prices ironically forces producers to reduce feed costs by using cheaper ingredients and lower feed specifications (Halteren et al., 2009). There are more than 35 low price raw materials found locally in Bangladesh can be used in the preparation of supplementary feed of fish and shrimp (Ali and Hoq, 2010). In feed development, there should have a provision of continuous investigation of raw materials and feed management in the mills and industry.

Due to increased aquaculture practice, demand of good quality feed is increasing day by day. Prime quality feed is essential for fish growth. Maintaining feed conversion ratio (FCR) close to 1 highly depends upon good feed. Feed should have adequate protein content which facilitates high growth. Net protein utilization should be around 27 percent. Feed should also contain suitable amounts of energy source, minerals and vitamins.

With the aim of increased aquaculture production through applying adequate feed large numbers of feed industries are developed in the country. But most of the feed industries fail to produce high quality feed due to unavailability of quality feed ingredients, presence of adulterated ingredients, presence of harmful antibiotics etc. On the other hand feed and labor comprise the two most important components of the total operating cost for most culture systems in Bangladesh. To maintain high quality of finished feed good administrative structure of a feed industry committed to produce quality feed is important.

\section{Materials and Methods}

Data were collected from different industries in Noakhali district during the period of 5 months from November 2014 to April 2015 by on the spot data collections. Several interviews were conducted in study site with executive manager, manager, labor and local people. Obtaining information through various assessment tools including FGD (focus group discussion), in-depth interviews individual and key informant interviews with semi-structured questionnaires to collect information from different fish feed industries. The questionnaire was prepared in accordance with the objectives of study. The questionnaire has two parts, one includes personal information and the other includes farm information. Information from each industry was little different from others. Secondary information from various sources was collected and reviewed.

\section{Results and Discussion}

\subsection{Overview of selected feed industries}

The study was conducted to achieve detailed information about the activities practiced in Globe-agro vat Limited, Partex agro fish feed limited, Setu feed mills and R.P (Rasulpur) fish feed limited.

It was observed that fish feed companies were increasing day by day and demand of fish feed also increasing for commercial fish culture (Table 1). Feed companies are linked with other business. Which companies are related to other business, their investment is high, having enriched machineries, good laboratory facility because of other income source. Some companies take loan from local NGO and foreign organization. From surveyed information it was showed that which companies were linked to local NGO, their farm area, staff number, investment were much better than other and their production capacity was also high. Globe agro vat Ltd. took loan from local and foreign organization at their starting point. This company is well developed than others. With the aim of increased aquaculture production through applying adequate feed large numbers of feed industries are developed in the country. But most of the feed industries fail to produce high quality feed due to unavailability of quality feed ingredients, presence of adulterated ingredients, presence of harmful antibiotics etc. (Mahmud, 2010).

\subsection{Machineries}

Maximum machineries were found in Globe-agro vet Limited. Some are found all of them fish feed industries. There is a unique machine which is found in only 1 industries and it is Pulverazier. It is found in Globe-agro vat Limited (Table 2).

\subsection{Raw materials}

Fish feed companies were used different types of raw materials. They used 19 types of raw materials. Maximum raw materials were found in Globe-agro vet Limited and they used 16 types of raw materials. Where Partex agro fish feed limited, setu feed mills and R.P (Rasulpur) fish feed limited used respectively 10, 12 and 10 types of 
raw materials. There also found 5 types of raw materials which were common in four feed industries and these were soybean meal, Rice polish, Fish meal, Lime stone and Rape seed meal (Table 3).

During manufacture of fish feed, feed industries were used different types of raw materials in which some were local and some were imported. Meat and bone meal, dry fish, fish meal, Rape seed, soybean meal having high content of protein are used as protein sources and rice polish, oil are used as lipid source and vitamin pre mix, mineral, binder, additives, enzymes were also used.

The effect of three low cost feeds, containing different protein levels, on growth performance and economics of walking catfish (Clarias batrachus) were studied by Samad et al., 2014 in earthen ponds for a period of 120 days. The experiment was conducted under three treatments of dietary protein levels viz. T1: $30 \%$ protein level, T2: $27 \%$ protein level and T3: $24 \%$ protein level. Research findings indicated that the production and net profit were significantly higher with treatment $\mathrm{T} 1$ (diet $1 ; 30 \%$ protein level: poultry viscera, $36.23 \%+$ mustard oil cake, $36.23 \%+$ rice polish, $27.52 \%$ ) in trial.

\subsection{Finished product}

Globe agro vat Ltd produced Four types of fish feed where Partex fish feed Ltd produced two types, setu feed mills produced two types and R.P (Rasulpur) fish feed Ltd produced 2 types of feed .Among these feeds, nursery and finisher were produced in Globe agro vat Ltd which was not fund in other three feed industries to produce. Starter feed was produced in three feed industries among four industries. Among these feed, Grower feed was common which found every industries (Table 4).

Table 1. Overview of different fish feed industries.

\begin{tabular}{|c|c|c|c|c|c|}
\hline & Established Year & Area & Manpower & Total investment & Production capacity \\
\hline $\begin{array}{l}\text { Globe-agro Vet } \\
\text { Limited }\end{array}$ & $2012-2013$ & 9 Acre & 110 & 24 Core & 130 ton/day \\
\hline $\begin{array}{l}\text { Partex Agro Fish } \\
\text { Feed Limited }\end{array}$ & 2010 & 3 Acre & 50 & 5 Core & 20 ton/day \\
\hline $\begin{array}{l}\text { Setu Feed Mills } \\
\text { R.P (Rasulpur) Fish } \\
\text { Feed Limited }\end{array}$ & $\begin{array}{l}2012 \\
2011\end{array}$ & $\begin{array}{l}2 \text { Acre } \\
3.5 \text { Acre }\end{array}$ & $\begin{array}{l}40 \\
70\end{array}$ & $\begin{array}{l}3 \text { core } \\
7 \text { Core }\end{array}$ & $\begin{array}{l}15 \text { ton /day } \\
30 \text { Ton/day }\end{array}$ \\
\hline
\end{tabular}

Table 2. Arrangement of machineries among the farms.

\begin{tabular}{|c|c|c|c|c|c|}
\hline & $\begin{array}{l}\text { Globe-agro Vet } \\
\text { Limited }\end{array}$ & $\begin{array}{l}\text { Partex Agro Fish } \\
\text { Feed Limited }\end{array}$ & $\begin{array}{l}\text { Setu Feed } \\
\text { Mills }\end{array}$ & $\begin{array}{l}\text { R.P (Rasulpur) } \\
\text { Fish Feed Limited }\end{array}$ & $\begin{array}{l}\text { Total } \\
(\%)\end{array}$ \\
\hline Hammer mill & $\checkmark$ & $\checkmark$ & $\checkmark$ & $\checkmark$ & $4(11.43 \%)$ \\
\hline Mixer & $\checkmark$ & $\checkmark$ & $\checkmark$ & $\checkmark$ & $\begin{array}{c}4 \\
(11.43 \%)\end{array}$ \\
\hline Pulverizer & $\checkmark$ & $x$ & $x$ & $x$ & $\begin{array}{c}1 \\
(2.8 \%)\end{array}$ \\
\hline Pellet mill & $\checkmark$ & $\checkmark$ & $\checkmark$ & $\checkmark$ & $\begin{array}{c}4 \\
(11.43 \%)\end{array}$ \\
\hline Drum shifter & $\checkmark$ & $\checkmark$ & $\checkmark$ & $\checkmark$ & $\begin{array}{c}4 \\
(11.43 \%)\end{array}$ \\
\hline Storage bin & $\checkmark$ & $\checkmark$ & $\checkmark$ & $\checkmark$ & $\begin{array}{c}4 \\
(11.43 \%)\end{array}$ \\
\hline Sieve & $\checkmark$ & $\checkmark$ & $\checkmark$ & $\checkmark$ & $\begin{array}{c}4 \\
(11.43 \%)\end{array}$ \\
\hline Wing scale & $\checkmark$ & $\checkmark$ & $\checkmark$ & $\checkmark$ & $\begin{array}{c}4 \\
(11.43 \%)\end{array}$ \\
\hline $\begin{array}{l}\text { Automatic } \\
\text { system }\end{array}$ & $\checkmark$ & $x$ & $x$ & $\checkmark$ & $\begin{array}{c}2 \\
(5.71 \%)\end{array}$ \\
\hline $\begin{array}{l}\text { Cooling and } \\
\text { drying machine }\end{array}$ & $\checkmark$ & $\checkmark$ & $\checkmark$ & $\checkmark$ & $\begin{array}{c}4 \\
(11.43 \%)\end{array}$ \\
\hline $\begin{array}{l}\text { Total } \\
(\%)\end{array}$ & $\begin{array}{c}10 \\
(28.575 \%)\end{array}$ & $\begin{array}{c}8 \\
(22.87 \%)\end{array}$ & $\begin{array}{c}8 \\
(22.87 \%)\end{array}$ & $\begin{array}{c}9 \\
(25.71 \%)\end{array}$ & $\begin{array}{l}35 \\
(100 \%)\end{array}$ \\
\hline
\end{tabular}


Asian J. Med. Biol. Res. 2017, 3 (4)

Table 3. Used raw materials in different feed industries.

\begin{tabular}{|c|c|c|c|c|c|}
\hline & $\begin{array}{l}\text { Globe-agro Vet } \\
\text { Limited }\end{array}$ & $\begin{array}{l}\text { Partex Agro Fish } \\
\text { Feed Limited }\end{array}$ & $\begin{array}{l}\text { Setu Feed } \\
\text { Mills }\end{array}$ & $\begin{array}{l}\text { R.P (Rasulpur) } \\
\text { Fish Feed } \\
\text { Limited }\end{array}$ & $\begin{array}{l}\text { Total } \\
\text { (\%) }\end{array}$ \\
\hline Maize & & $x$ & $x$ & $x$ & $1(2.08 \%)$ \\
\hline Wheat & & $x$ & $x$ & $x$ & $1(2.08 \%)$ \\
\hline Soybean meal & & & & & $4(8.33 \%)$ \\
\hline Rice Bran & & $x$ & & & $3(6.25 \%)$ \\
\hline Rice Polish & & & & & $4(8.33 \%)$ \\
\hline Fish meal & & & & & $4(8.33 \%)$ \\
\hline Meat and Bone meal & & & & $x$ & $3(6.25 \%)$ \\
\hline Oil Cake & & $x$ & $x$ & $x$ & $1(2.08 \%)$ \\
\hline Lime stone & & & & & $4(8.33 \%)$ \\
\hline Cottonseed meal & & $x$ & $x$ & $x$ & $1(2.08 \%)$ \\
\hline Salt & & $x$ & & & $3(6.25 \%)$ \\
\hline Molasses & & $x$ & $x$ & $x$ & $1(2.08 \%)$ \\
\hline Dry fish & $x$ & & & & $3(6.25 \%)$ \\
\hline Corn & $x$ & & & & $3(6.25 \%)$ \\
\hline Rape seed meal & & & & & $4(8.33 \%)$ \\
\hline DORB-powder & & & & & $2(4.16 \%)$ \\
\hline & $x$ & & & $x$ & \\
\hline $\begin{array}{l}\text { Vitamin-Mineral } \\
\text { Premix }\end{array}$ & & & $x$ & $x$ & $2(4.16 \%)$ \\
\hline Enzyme & & $x$ & & & $3(6.25 \%)$ \\
\hline Growth promoter & & $x$ & $x$ & $x$ & $1(2.08 \%)$ \\
\hline $\begin{array}{l}\text { Total } \\
(\%)\end{array}$ & $16(33.33 \%)$ & $10(20.83 \%)$ & $12(25 \%)$ & $10(20.83 \%)$ & $48(100 \%)$ \\
\hline
\end{tabular}

Table 4. Produced finished product among the farms.

\begin{tabular}{|c|c|c|c|c|c|}
\hline & $\begin{array}{l}\text { Globe-agro } \\
\text { Limited }\end{array}$ & $\begin{array}{ll}\text { Partex } & \text { Agro } \\
\text { Fish } & \text { Feed } \\
\text { Limited } & \end{array}$ & Setu Feed Mills & $\begin{array}{l}\text { R.P (Rasulpur) } \\
\text { Fish Feed Limited }\end{array}$ & $\begin{array}{l}\text { Total } \\
(\%)\end{array}$ \\
\hline Nursery & $\checkmark$ & $x$ & $x$ & $x$ & $\begin{array}{l}1 \\
(4.54 \%)\end{array}$ \\
\hline $\begin{array}{l}\text { Starter-1 } \\
\text { Starter-2 } \\
\text { Starter-3 }\end{array}$ & $\checkmark$ & $\checkmark$ & $\checkmark$ & $\checkmark$ & $\begin{array}{l}12 \\
(54.54 \%)\end{array}$ \\
\hline Grower-1 & $\checkmark$ & $\checkmark$ & $\checkmark$ & $\checkmark$ & $\begin{array}{l}8 \\
(36,36 \%)\end{array}$ \\
\hline Finisher & $\checkmark$ & $x$ & $x$ & $x$ & $\begin{array}{l}1 \\
(4.54 \%)\end{array}$ \\
\hline $\begin{array}{l}\text { Total } \\
(100 \%)\end{array}$ & $7(31.81 \%)$ & $5(22.73 \%)$ & $5(22.73 \%)$ & $5(22.73 \%)$ & $\begin{array}{l}22 \\
(100 \%)\end{array}$ \\
\hline
\end{tabular}

Table 5. Variation of proximate compositions among four companies.

\begin{tabular}{|c|c|c|c|c|}
\hline & Protein (\%) & Lipid (\%) & $\operatorname{Ash}(\%)$ & Moisture (\%) \\
\hline Globe-agro Vet Ltd. & $28-35 \%$ & $5-6 \%$ & $12-18 \%$ & $10-12 \%$ \\
\hline $\begin{array}{l}\text { Partex Agro Fish } \\
\text { Feed Limited }\end{array}$ & $28 \%$ & $8 \%$ & $18 \%$ & $11 \%$ \\
\hline Setu Feed Mills & $28-32 \%$ & $8 \%$ & $15-18 \%$ & $10-11 \%$ \\
\hline $\begin{array}{l}\text { R.P (Rasulpur) Fish } \\
\text { Feed Limited }\end{array}$ & $28-30 \%$ & $5-7 \%$ & $12-18 \%$ & $10-12 \%$ \\
\hline
\end{tabular}


Table 6. Seasonal variation of produced product.

\begin{tabular}{ll}
\hline Name of company & Month \\
\hline Globe-agro Vet Limited & April to October \\
Partex Agro Fish Feed Limited & March to July \\
Setu Feed Mills & April to June \\
R.P (Rasulpur) Fish Feed Limited & March to April \\
\hline
\end{tabular}

Maximum feed industries were emphasized on producing starter and grower feed. Since demand of starter and grower feed are increasing with commercial fish culture, maximum feed industries like to produce these types of feed. Surveyed areas showed that surrounding area was important for fish feed company. Nursery pond was found at maximum rate near the company and they were liked to fulfill local demand by producing nursery feed.

\subsection{Proximate composition of finished product}

Proximate composition was not so differ among four feed companies. Protein was ranges from 28 - $35 \%$, lipid was 5-6 \%, Ash was 12-18 \%, and moisture was 10-12\% in Globe-agro vat Limited. In Partex agro fish feed limited proximate compositions were protein $28 \%$, lipid $8 \%$, Ash $18 \%$, Moisture $11 \%$. In setu feed mills the proximate composition of feed were protein $28-32 \%$, Lipid $8 \%$, Ash 15-18\%. Protein 28-30 \%, Lipid 5-7 \%, Ash 12-18 \% and moisture 10-12 \% in R.P (Rasulpur) fish feed limited (Table 5).

Alam et al. (2012) conducted survey in Fulpur upazila under Mymensingh district maximum crude protein content was found in Nourish fish feed (31.67\%) and the minimum crude protein was in ACI fish feed (23.15\%). The mean crude lipid values of ACI fish feed, Nourish fish feed, Mega fish feed, Aftab fish feed, CP fish feed, Saudi Bangla fish feed and Quality fish feed are 6.93\%, 8.60\%, 8.12\%, 6.40\%, $11.13 \%, 9.66 \%$, and $9.60 \%$, respectively. The maximum crude lipid was found in CP fish feed (11.13\%) and the minimum crude lipid was in ACI fish feed (6.93\%). The mean ash values of ACI fish feed, Nourish fish feed, Mega fish feed, Aftab fish feed, CP fish feed, Saudi Bangla fish feed and Quality fish feed are 8.51\%, 15.65\%, 23.15\%, 24.40\%, $21.11 \%, 19.15 \%$, and $23.01 \%$, respectively. The maximum ash was found in Aftab fish feed $(24.40 \%)$ and the minimum was in ACI fish feed (8.51\%). The mean moisture value of ACI fish feed, Nourish fish feed, Mega fish feed, Aftab fish feed, CP fish feed, Saudi Bangla fish feed and Quality fish feed are $11.77 \%, 10.38 \%$, $10.06 \%, 17.72 \%, 11.76 \%, 10.95 \%$ and $12.93 \%$, respectively.

\subsection{Seasonal variation}

The studied area showed there was seasonal variation on producing finished product. Globe-agro vet Limited produced product maximum from April to October. Where partex agro fish feed limited, setu feed mills and R.P (Rasulpur) fish feed limited produced feed respectively from March to July, April to June and March to April (Table 6).

The surveyed companies showed that their production capacity was not same rate all round the year. They were like to producing feed at March to October. Because of production of feed is depending upon the season. In winter season fish grow slowly and take little amount of feed, thus requirement is low while in summer season fish take more feed and grow rapidly thus requirement is high.

Mahmud (2010) conducted survey on comparison of nutritional composition of pungus grower, pungus starter, koi grower that Feed production is generally highest in June, July, August and September and then the production is gradually decreased.

\section{Conclusions}

The growth of commercial aquaculture and commercial aquafeed production in Bangladesh over the preceding 5-10 years has been remarkable and yet there is considerable room for further expansion of both sectors over the medium to long term. The rate of expansion in the production and uptake of manufactured feeds has been so rapid that the industry has not yet matured fully. So, help is needed to support the aquaculture industry as it continues to expand and modernize. Fish feed companies are increasing day by day without any environmental consideration. Adjacent area of feed companies are affecting large by foul smelling, continuous sounding, waste disposal and transportation destruction. The government should be promoted to enhance the modernization of fish feed industries and reducing environmental hazards caused by them.

\section{Conflict of interest}

None to declare. 


\section{References}

Alam MK, MAB Habib and MS Tahmid, 2012. A survey on commercial fish feed used at Fulpur area in Mymensingh district. J. Bangladesh Agril. Univ., 10: 175-178.

Ali MZ and ME Hoq, 2010. Improved Fish feed Management in Aquaculture. Extension Manual No. 38. Bangladesh Fisheries Research Institute, Mymensingh.

DoF, 2009-10. Fishery Statistical Yearbook of Bangladesh 2009-10. Fisheries Resources Survey System, Department of Fisheries, Ministry of Fisheries and Livestock, Matshya Bhaban, Dhaka, Bangladesh.

DoF, 2009-10. Brief on Department of Fisheries Bangladesh. Department of Fisheries, Ministry of Fisheries and Livestock, Dhaka, Bangladesh.

FAO/UNDP, 198. Twenty Year Fisheries Development Plan for Bangladesh. Prepared by John C. Marr Associates, Temecula. California, USA.

Halteren A, V Phong, NV Larn, HD Nguyen and P Coutteau, 2009. Optimizing the application of a novel feed additive to improve feed utilization and fillet yield in Pangasius catfish farming. AQUA Culture Asia Pacific Magazine.

Hossain MM, 2003. Quality control program for the extension of export business. In: Fish Fortnight Compendium. Department of Fisheries, Ministry of Fisheries and Livestock, Bangladesh.

Mahmud MS, 2010. An overview of a fish feed industry and its operational \& management approaches. AquaInternship Program Report. Faculty of Fisheries, Bangladesh Agricultural University, Mymensingh-2202.

Mollah MFA and MA Hossain, 1990. Effects of artificial diets containing different protein levels on growth and feed efficiency of catfish (Clarias batrachus). Indian J. Fish., 37: 251-259.

Rashid MM, B Belton, M Phillips, M Karim, 2013a. The Current status of aquaculture and aquafeed production in Bangladesh. World Aquaculture Magazine, 44: 23-27.

Rashid MM, B Belton, M Phillips and KA Rosentrater, 2013b. Improving aquaculture feed in Bangladesh: From feed ingredients to farmer profit to safe consumption. WorldFish, Penang, Malaysia.

Samad MA, AM Imteazzaman, MI Hossain and MS Reza, 2014. Effects of three different low cost feeds on growth performance of walking catfish (Clarias batrachus L.) in earthen ponds. Rajshahi University Journal of Life \& Earth and Agricultural Science, 42: 1-10. 